\title{
Simulasi Aplikasi PLC Sebagai Sistem Proteksi Arus Dan Temperatur Lebih Pada Motor Induksi Tiga Fasa
}

\author{
Sophia Latifah Aulia ${ }^{1}$, Toto Tohir ${ }^{2}$, Kartono W. ${ }^{3}$ \\ 1,2,3 Jurusan Teknik Elektro, Politeknik Negeri Bandung, Bandung 40012 \\ ${ }^{I}$ E-mail : sophia.latifah.tlis18@polban.ac.id \\ ${ }^{2}$ E-mail : toto.tohir@polban.ac.id \\ ${ }^{3}$ E-mail : karwij@gmail.com
}

\begin{abstract}
ABSTRAK
Sistem proteksi pada motor induksi tiga fasa merupakan suatu cara yang dilakukan agar motor dapat digunakan dalam jangka waktu yang lebih panjang dan terhindar dari kerusakan. Gangguan seperti arus dan temperatur lebih yang terjadi karena adanya hubung singkat ataupun beban lebih dapat mengganggu kinerja dari motor induksi dan dapat memperpendek waktu penggunaannya. Maka dari itu suatu sistem proteksi pada motor induksi sangat dibutuhkan. Metode yang digunakan pada makalah ini yaitu perancangan simulasi sistem proteksi arus dan temperatur lebih pada motor induksi tiga fasa dengan mengaplikasikan Programmable Logic Control (PLC) menggunakan perangkat lunak CX-One dengan membuat diagram Ladder juga simulasinya dan membuat desain dalam bentuk gambar tiga dimensi menggunakan perangkat lunak SketchUp. Untuk memproteksi motor induksi tiga fasa digunakan suatu komponen yaitu Over Current Relay (OCR) untuk arus lebih dan Temperature Controller untuk temperatur lebih. Batas maksimum arus yang akan diproteksi OCR adalah sebesar 3.421 A dan batas temperatur maksimum yang akan diproteksi Temperature Controller yaitu sebesar $100^{\circ} \mathrm{C}$. Kedua komponen tersebut diintegrasikan oleh PLC. Tahapan proses dari programnya itu sendiri, OCR dan atau Temperature Controller akan mengirimkan sinyal trip menuju PLC ketika terjadi gangguan arus atau temperatur lebih kemudian PLC akan mengamankan motor dari gangguan tersebut dengan menghentikan daya menuju motor.
\end{abstract}

Kata Kunci

Proteksi Motor, PLC, OCR, Temperature Controller, Motor Induksi Tiga Fasa.

\section{PENDAHULUAN}

Motor induksi merupakan salah satu jenis dari motor listrik yang banyak digunakan pada industri kecil maupun besar. Motor induksi dipergunakan karena mempunyai banyak keunggulan, seperti memiliki bentuk yang sederhana juga konstruksi yang kuat, biaya yang murah dan bisa diandalkan. Selain itu, motor induksi sangat efisien dalam kondisi normal dan juga tidak memerlukan sikat, sehingga kerugian gesekan dapat diminimalkan, perawatan juga minimal dan tidak memerlukan peralatan khusus pada saat waktu mulai [1].

Terlepas dari beberapa kelebihan yang dimiliki, motor induksi tiga fasa terkadang dapat mengalami beberapa permasalahan seperti arus lebih (Over Current) atau arus start yang besar yang terjadi ketika motor induksi kelebihan beban (Overload) ataupun mengalami hubung singkat (Short Circuit). Arus tidak boleh melebihi arus beban penuh atau In yang tertera dalam name plate motor. Apabila motor bekerja dengan beban yang melebihi kemampuan motor, maka motor akan menjadi terlalu panas dan akan mengalami kerusakan dalam jangka waktu tertentu, oleh karena itu diperlukan pemasangan sistem proteksi pada motor induksi tiga fasa [1].

Thermal Overload Relay (TORL) biasa digunakan dalam sistem proteksi pada motor induksi tiga fasa, namun proteksi menggunakan TOLR ini terdapat beberapa kekurangan seperti, TOLR perlu dikendalikan dengan kontaktor, TOLR juga tidak memiliki sistem monitoring, usia pemakaian dari TOLR juga pendek dan apabila Timer Start-Trip mengalami kerusakan ketika motor beroperasi maka saat terjadi gangguan motor induksi tidak akan terjadi trip. Hal tersebut akan mengakibatkan kerusakan pada motor karena proteksi yang tidak bisa bekerja [2].

Motor induksi dapat mengalami kerusakan seperti arus gangguan yang besarnya melebihi dari arus kerja motor induksi tersebut yang disebabkan oleh gangguangangguan seperti gangguan hubung singkat, beban lebih dan arus bocor ketanah. Maka untuk mengatasi gangguan-gangguan tersebut, dibutuhkan sistem proteksi yang handal dalam mengatasi gangguangangguan yang merugikan pada motor induksi tiga fasa [3].

Oleh karena itu diperlukan sistem proteksi tambahan yang dapat mengamankan motor induksi tiga fasa dari arus dan temperatur lebih yaitu dengan menggunakan OCR dan Temperature Controller yang terintegrasi dengan PLC, sehingga sistem proteksi ini dapat dioperasikan secara semi-otomatis.

\section{LANDASAN TEORI}

\subsection{Sistem Proteksi}

Sistem proteksi adalah suatu cara yang digunakan untuk mencegah sistem dari kerusakan akibat gangguan dan untuk mempertahankan kelangsungan sistem tersebut [4]. 


\subsubsection{Proteksi Arus Lebih Pada Motor Induksi}

Arus Lebih atau Over Current adalah sebuah gangguan arus dimana arus yang mengalir pada rangkaian melebihi arus normal pada saat motor dibeban penuh atau Full Load Amps (FLA)[4]. Arus nominal atau FLA merupakan jumlah maksimum dari arus normal yang dapat diterima motor tanpa mengalami gangguan, lalu untuk menentukan arus nominal dan arus setting untuk memproteksi motor dari arus lebih dapat dicari menggunakan perhitungan dengan persamaan sebagai berikut [5]:

$$
\begin{aligned}
& I_{n}=\frac{P}{V \times \operatorname{Cos} \varphi} \\
& I_{\text {Set }}=I_{n} \times 110 \%
\end{aligned}
$$

\subsubsection{Proteksi Temperatur Lebih Pada Motor} Induksi

Kenaikan temperatur menurut NEMA adalah kenaikan temperatur diatas ambient temperatur atau suhu ruangan. Spesifikasi temperatur motor induksi pada umumnya memiliki kelas $\mathrm{F}$ dengan batas temperatur sesuai dengan tabel 1 :

Tabel 1. Kenaikan suhu untuk motor besar dengan

\begin{tabular}{|c|c|c|c|c|c|}
\hline \multirow{2}{*}{ No. } & \multirow{2}{*}{ Motor Rating } & \multicolumn{4}{|c|}{$\begin{array}{l}\text { Insulation Class and } \\
\text { Temperature Rise }{ }^{\circ} \mathrm{C}\end{array}$} \\
\hline & & $\mathrm{A}$ & $\mathrm{B}$ & $\mathrm{F}$ & $\mathrm{H}$ \\
\hline 1. & $\begin{array}{c}\text { All horsepower (or kW) } \\
\text { ratings }\end{array}$ & 60 & 80 & 105 & 125 \\
\hline 2. & $1500 \mathrm{HP}(1120 \mathrm{~kW})$ an less & 70 & 90 & 115 & 140 \\
\hline 3. & $\begin{array}{l}\text { Over } 1500 \mathrm{HP}(1120 \mathrm{~kW}) \\
\text { and } 7000 \text { volt or less }\end{array}$ & 65 & 85 & 110 & 135 \\
\hline 4. & $\begin{array}{l}\text { Over } 1500 \mathrm{HP}(1120 \mathrm{~kW}) \\
\text { and over } 700 \text { volt }\end{array}$ & 60 & 80 & 105 & 125 \\
\hline
\end{tabular}
factor servis 1.0 [6]

\subsection{Motor Induksi}

Motor induksi merupakan motor listrik arus bolak-balik (AC) yang banyak digunakan dalam industri. Motor induksi memiliki tiga bagian, yaitu stator, rotor dan celah. Prinsip kerja dari motor induksi itu sendiri bekerja berdasarkan prinsip elektromagnetik [7].

\subsection{Programmable Logic Control}

Programmable Logic Controllers (PLC) adalah komputer elektronik yang mudah digunakan (user friendly). Prinsip kerja dari PLC adalah untuk memonitor sebuah keadaan dari peralatan masukan yang kemudian masukan tersebut dianalisis untuk mengontrol keadaan sebuah keluaran yang sesuai dengan kebutuhan perencana. Sinyal masukan diberikan ke dalam card keluaran [8].

\subsection{Over Current Relay}

OCR atau singkatan dari Over Current Relay adalah relai yang berfungsi untuk mendeteksi adanya arus lebih yang melewati dari batas arus setting melalui CT atau trafo arus dan akan mengirikan sinyal trip menuju PMT atau pemutus tenaga [9]. Terdapat tiga karakteristik pada OCR yaitu Instantaneous relay, Definite time relay dan Inverse time relay.

\subsection{Temperature Controller}

Temperature Controller merupakan suatu peralatan elektronik yang mempunyai fungsi sebagai regulator temperatur. Temperature Controller bekerja dengan cara membandingkan dua sinyal yaitu sinyal sensor dengan sinyal referensi yang selanjutnya akan dilakukan penghitungan deviasi yang digunakan. Temperature Controller mempunyai dua metode kontrol yaitu PID dan ON/OFF [10].

\subsection{Perangkat Lunak CX-One}

CX-One Merupakan paket perangkat lunak yang mempunyai cakupan yang luas. Perangkat lunak CXOne ini terdiri dari beberapa perangkat lunak dan tools tambahan yang telah disediakan untuk mendukung sistem kerja PLC OMRON, seperti CX-Programmer dan CX-Designer.

CX-Programmer adalah perangkat yang digunakan untuk membuat pemrograman diagram Ladder dan mempunyai fitur simulasi yang dapat berjalan tanpa dihubungkan dengan PLC [11]. Lalu CX-Designer merupakan perangkat lunak HMI yang dibuat OMRON yang dapat memvisualisasikan PLC dengan sebuah layar tampilan yang dapat didesain untuk sebuah proses, peristiwa atau kejadian yang terjadi pada plant sehingga dapat mudah untuk memonitor.

\subsection{Perangkat Lunak SketchUp}

SketcthUp adalah perangkat lunak yang digunakan untuk membuat juga mengedit sebuah model dalam bentuk dua ataupun tiga dimensi dengan cara teknik "push and pull" [12].

\section{METODOLOGI PENELITIAN}

Metode yang digunakan pada penelitian ini yaitu perancangan simulasi, yang mana tahapannya terdiri dari perancangan diagram blok, diagram kontrol, diagram alir dan perancangan pada perangkat lunak yaitu pembuatan desain dalam bentuk gambar tiga dimensi yang dibuat pada perangkat lunak SketchUp, lalu pembuatan diagram Ladder pada perangkat lunak CX-Programmer dan pembuatan tampilan simulasi menggunakan perangkat lunak CX-Designer.

Cara kerja dari sistem proteksi ini adalah pada saat motor induksi tiga fasa mengalami gangguan yang mana akan menyebabkan naiknya arus melebihi batas dari tahanan isolasi pada stator motor, arus yang melebihi dari arus setting OCR tersebut akan terdeteksi oleh OCR kemudian akan mengirimkan sinyal menuju PLC untuk membuka kontak yang mulanya normali close (NC) menjadi open sehingga akan menghentikan kerja dari motor induksi. Dan sama halnya ketika terjadi gangguan yang menyebabkan temperatur motor induksi naik melebihi batas yang telah diatur pada Temperature Controller, maka temperatur tersebut akan terdeteksi oleh Temperature Controller yang dipilih pada kontrol ON/OFF lalu akan mengirimkan sinyal menuju PLC untuk membuka kontak yang mulanya NC menjadi open sehingga suplai motor induksi akan terputus lalu berhenti bekerja.

\subsection{Setting Arus Dan Temperatur}

Untuk menentukan setting dari OCR tipe definite, OCR yang digunakan adalah OCR Kasuga RAS70-3B, terdapat pertimbangan yang digunakan yaitu dari arus nominal motor pada kondisi bintang (Y) sebesar 3,11A. Maka untuk arus OCR disetting berdasarkan rumus (1)

$$
\mathrm{I}_{\text {Set }} \quad=\mathrm{I}_{\mathrm{n}} \times 110 \%
$$




$$
\begin{aligned}
& =3,11 \times 1,1 \\
& =3,421 \mathrm{~A}
\end{aligned}
$$

Dan untuk setting waktu OCR sebesar 0.46 detik dengan mempertimbangkan nilai dari $\mathrm{I}_{\text {Set }}$ OCR.

Kemudian untuk menentukan setting dari Temperature Controller yang digunakan pada sistem proteksi ini adalah Temperature Controller OMRON E5CC sebagai proteksi temperatur lebih, pertimbangan yang digunakan yaitu dari kelas isolasi dari motor induksi yang akan diproteksi yaitu kelas isolasi $\mathrm{F}$ dengan ambient temperatur tidak lebih dari $40^{\circ} \mathrm{C}$, berdasarkan tabel 1 . , batas maksimal kenaikan temperatur untuk kelas isolasi $\mathrm{F}$ adalah sebesar $105^{\circ} \mathrm{C}$, maka dari itu Temperature Controller akan disetting pada $100^{\circ} \mathrm{C}$ untuk menghindari terjadinya kerusakan pada isolasi lilitan. Metode kontrol yang digunakan adalah metode ONOFF.

\subsection{Diagram Blok}

Diagram blok simulasi sistem proteksi pada motor induksi tiga fasa ditunjukkan pada gambar 1 .

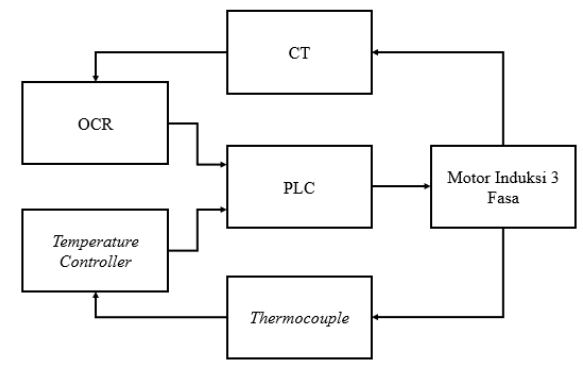

Gambar 1. Diagram Blok Simulasi Sistem Proteksi Berdasarkan diagram pada gambar 1 secara umum sistem ini dibuat untuk dapat memproteksi motor induksi tiga fasa dari gangguan arus dan temperatur lebih menggunakan OCR yang terhubung dengan CT yang mentransformasikan arus dan Temperature Controller yang terhubung dengan Thermocoupel sebagai sensor suhu dan dikoordinasi oleh PLC.

\subsection{Diagram Kontrol}

Diagram atau rangkaian kontrol adalah suatu rangkaian yang berperan untuk mengendalikan menghidupkan ataupun mematikan suatu sistem. Berikut ialah diagram kontrol dari sistem perlindungan motor induksi 3 fasa :

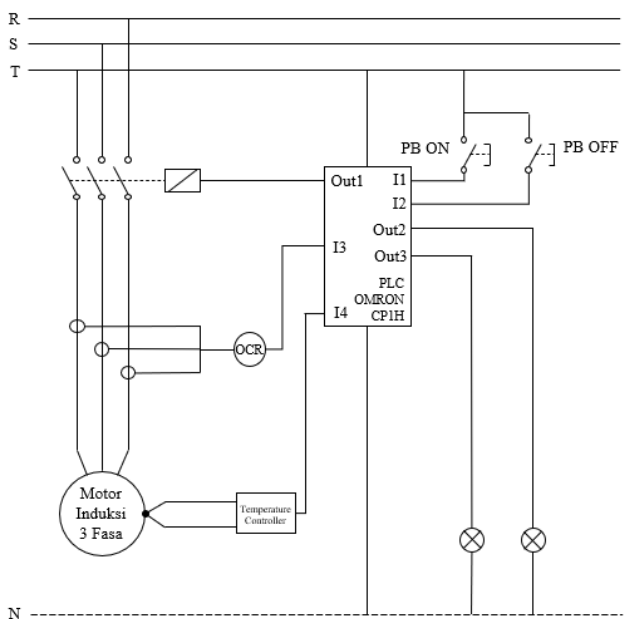

Gambar 2. Diagram Kontrol Simulasi Sistem Proteksi

\subsection{Diagram Alir}

Berikut merupakan diagram alir yang ditunjukkan pada gambar 3. yang menjelaskan untuk memulai program dilakukan dengan cara menekan push button on, kemudian PLC akan melakukan proses inisialisasi program untuk menentukan nilai setting dari OCR dan Temperature Controller dalam membaca nilai arus dan temperatur motor. Arus OCR disetting pada nilai 3,421 A sehingga ketika OCR mendeteksi adanya arus kurang dari 3,421 A maka motor akan tetap berjalan dan ketika OCR mendeteksi adanya arus lebih besar dari 3,421 A maka Motor akan berhenti bekerja. Dan untuk Temperature Controller disetting pada temperatur $100^{\circ} \mathrm{C}$ sehingga ketika Temperature Controller mendeteksi temperatur dibawah $100^{\circ} \mathrm{C}$ maka motor akan tetap bekerja dan ketika Temperature Controller mendeteksi adanya temperatur melebihi $100^{\circ} \mathrm{C}$ maka motor akan berhenti bekerja. Dan sistem akan terus berulang sesuai dengan arus dan temperatur motor.

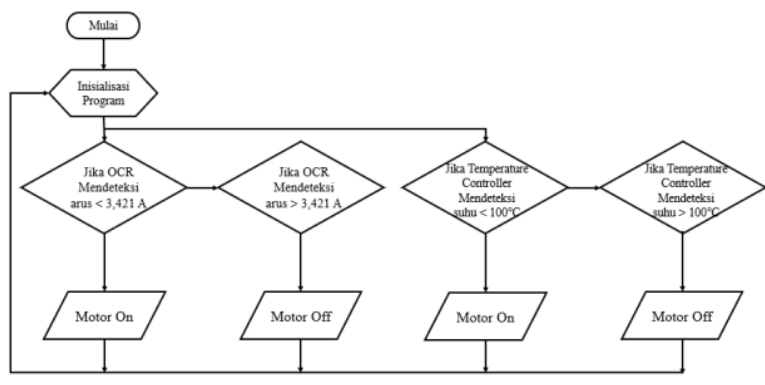

Gambar 3. Diagram Alir Simulasi Sistem Proteksi

\subsection{Desain Sistem Proteksi}

Desain sistem proteksi motor induksi tiga fasa ini dirancang dalam bentuk 3 dimensi menggunakan perangkat lunak SketchUp. Tujuan dibuatnya desain 3D ini bertujuan untuk membuat gambaran sistem proteksi ini apabila direalisasikan dalam bentuk perangkat kerasnya. Sistem ini terdiri dari beberapa komponen yang tersusun dalam sebuah panel dan terdapat motor induksi sebagai objek yang diproteksi. Untuk lebih jelasnya dapat dilihat pada gambar 4. dan gambar 5 .

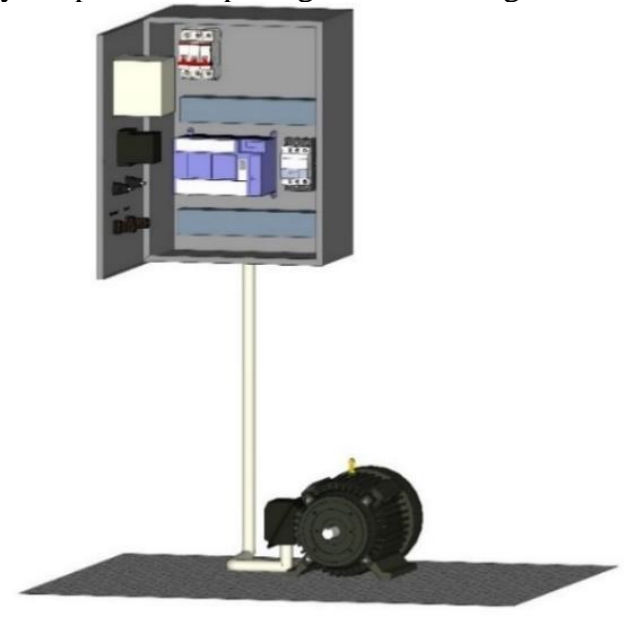

Gambar 4. Desain Sistem Proteksi Tampak Depan 


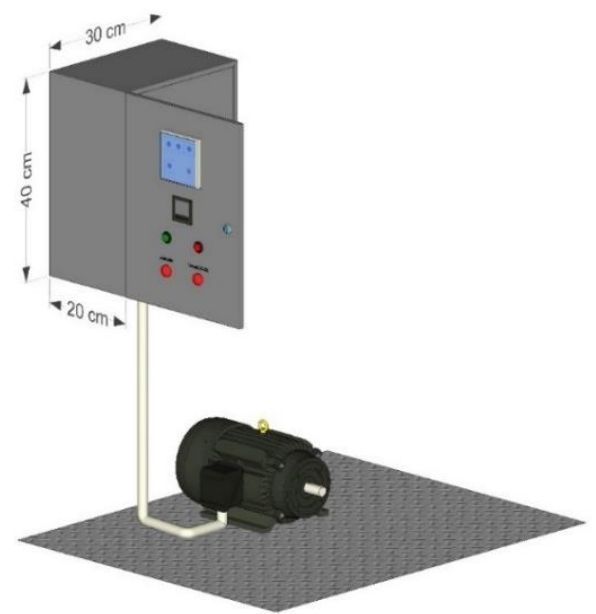

Gambar 5. Desain Sistem Proteksi Tampak Samping

\section{HASIL DAN PEMBAHASAN}

\subsection{TABEL Input Output}

Berikut merupakan Tabel 2. Yang menujukan Input dan Output, variabel juga alamat variabel yang terdapat pada Ladder diagram.

Tabel 2. Input Output

\begin{tabular}{ccccc}
\hline No. & Variabel & $\begin{array}{c}\text { Nama } \\
\text { Variabel }\end{array}$ & $\begin{array}{c}\text { Alamat } \\
\text { Variabel }\end{array}$ & Keterangan \\
\hline 1. & Input & PB ON & 0.00 & Push button On \\
\hline 2. & Input & PB OFF & 0.01 & Push button Off \\
\hline 3. & Input & OCR & 0.02 & Over Current Relay \\
\hline 4. & Input & TC & 0.03 & $\begin{array}{c}\text { Temperature } \\
\text { Controler }\end{array}$ \\
\hline 5. & Output & Kontaktor & 10.00 & Kontaktor Motor \\
\hline 6. & Output & L1 & 10.01 & $\begin{array}{c}\text { Lampu Indikator } \\
\text { Arus Lebih }\end{array}$ \\
\hline 7. & Output & L2 & 10.02 & $\begin{array}{c}\text { Lampu Indikator } \\
\text { Temperatur Lebih }\end{array}$ \\
\hline
\end{tabular}

\subsection{Ladder Diagram}

Berikut diagram Ladder yang telah dirancang pada CXProgrammer untuk sistem proteksi motor induksi tiga fasa dari suhu dan temperatur lebih ditunjukkan pada gambar 6. di bawah ini :

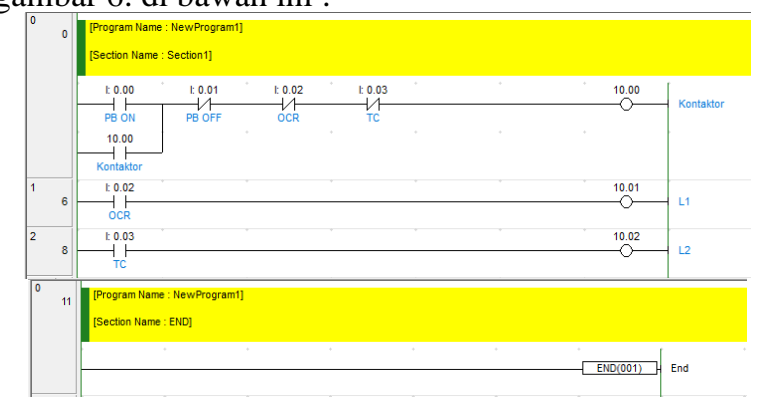

Gambar 6. Ladder Diagram Sistem Proteksi Motor Induksi Tiga Fasa

\subsection{Pengujian Ladder Diagram}

Pengujian Ladder Diagram dilakukan untuk melihat cara dari program yang telah dibuat, berikut merupakan hasil pengujian yang ditunjukkan pada gambar berikut :

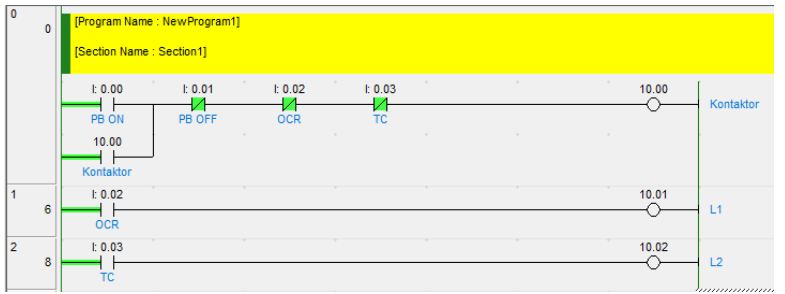

Gambar 7. Kondisi Ladder Diagram saat Off

Gambar 7. Menujukan kondisi diagram Ladder dalam keadaan off, disini motor induksi belum bekerja.

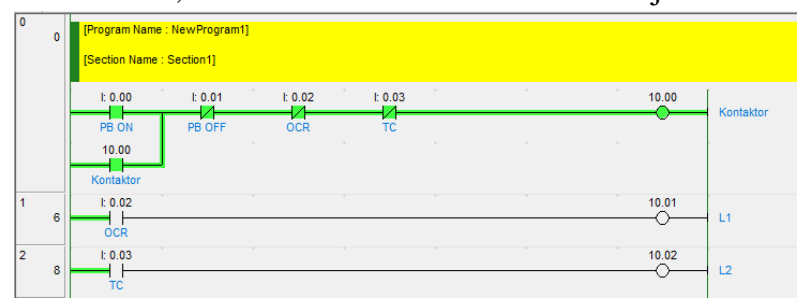

Gambar 8. Kondisi Ladder Diagram saat PB ON di tekan

Gambar 8. Menunjukkan kondisi diagram Ladder saat PB On ditekan, sehingga motor induksi bekerja.

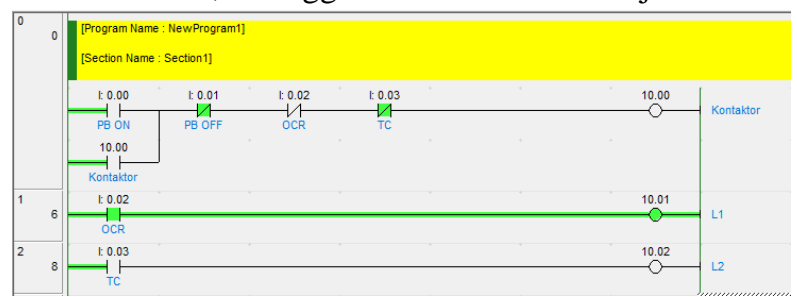

Gambar 9. Kondisi Ladder Diagram saat OCR aktif Gambar 9. Menunjukkan kondisi diagram Ladder ketika terjadi gangguan arus lebih. Kontak OCR akan terbuka sehingga suplai menuju motor terputus.

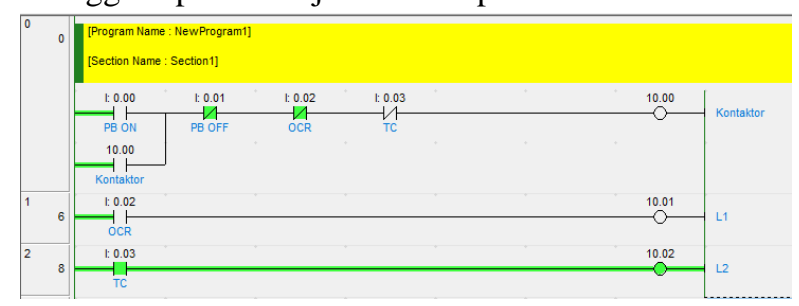

Gambar 10. Kondisi Ladder Diagram saat TC aktif

Gambar 10. Menunjukkan kondisi diagram Ladder ketika terjadi gangguan temperatur lebih. Kontak TC akan terbuka sehingga suplai menuju motor terputus.

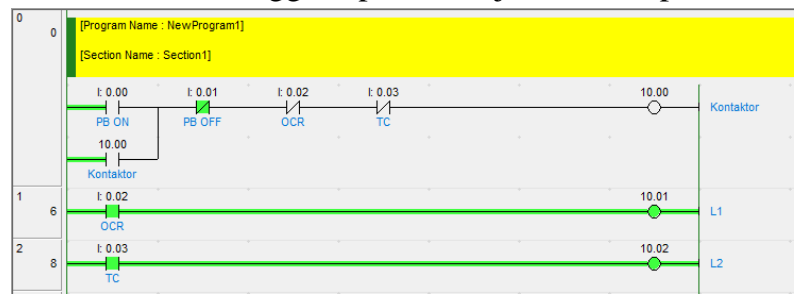

Gambar 11. Kondisi Ladder Diagram saat OCR dan TC Aktif

Gambar 11. Menunjukkan kondisi diagram Ladder ketika terjadi gangguan arus dan temperatur lebih. Kontak OCR dan TC akan terbuka sehingga suplai menuju motor terputus. 


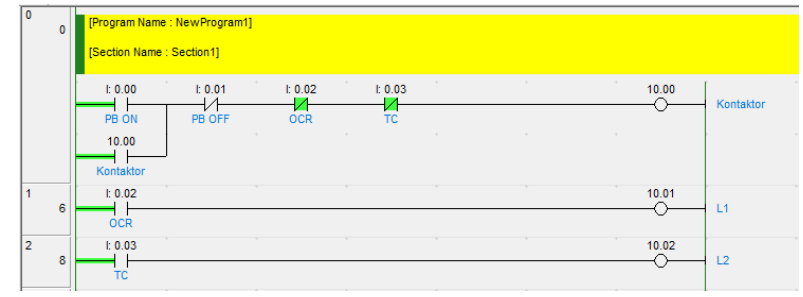

Gambar 12. Kondisi Ladder Diagram saat PB OFF ditekan

Gambar 12. Menunjukkan keadaan dimana PB Off ditekan sehingga motor induksi berhenti bekerja setelah selesai digunakan.

\subsection{Diagram Waktu}

Berikut merupakan gambar diagram waktu dari pengujian yang telah dilakukan pada diagram Ladder. Diagram waktu ini dibuat untuk mengamati keluaran I/O disaat keadaan High ataupun Low.

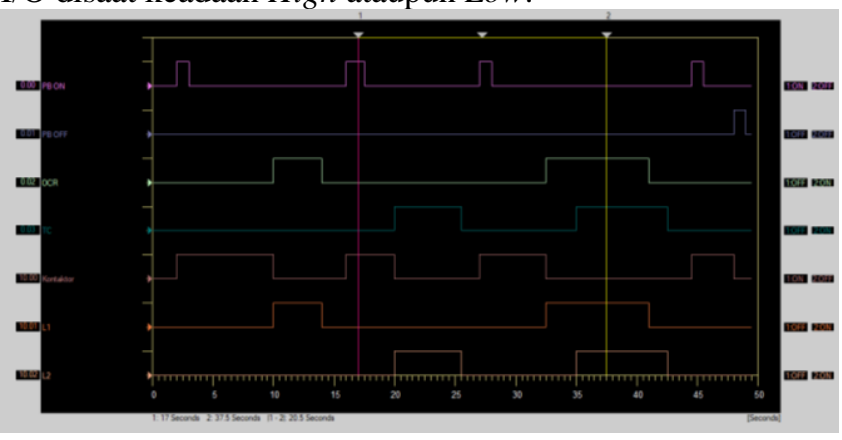

Gambar 13. Diagram Waktu

\subsection{SIMULASI CX-DESIGNER}

Berikut ini merupakan hasil simulasi dari Ladder Diagram yang telah diuji pada perangkat lunak CXProgrammer yang hasil tampilannya dioperasikan menggunakan perangkat lunak CX-Designer.

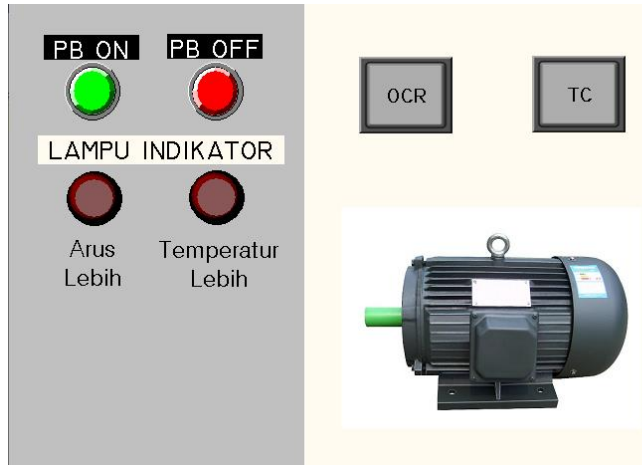

Gambar 14. Kondisi Off

Gambar 14. Menujukan tampilan sistem ketika dalam kondisi Off.. Motor belum beroperasi.

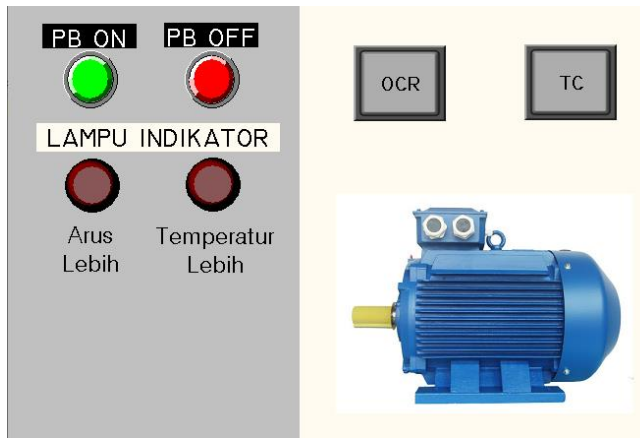

Gambar 15. Kondisi saat PB ON ditekan

Gambar 15. Menunjukkan kondisi motor yang menyala yang ditandakan motor berubah warna menjadi biru setelah PB On ditekan.

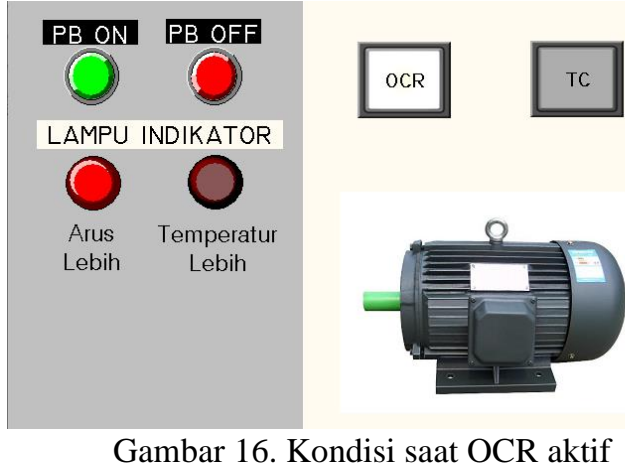

Gambar 16. Menunjukkan kondisi motor ketika terjadi gangguan arus lebih yang ditandakan warna abu pada motor, juga OCR aktif dan lampu indikator arus lebih menyala.

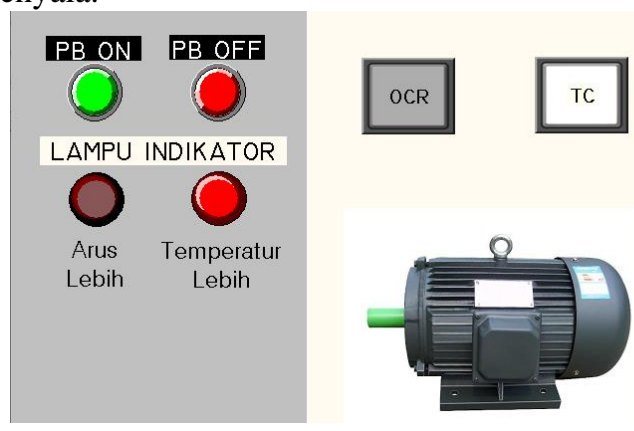

Gambar 17. Kondisi saat TC aktif

Gambar 17. Menunjukkan kondisi motor ketika terjadi gangguan arus lebih yang ditandakan warna abu pada motor, juga TC aktif dan lampu indikator temperatur lebih menyala.

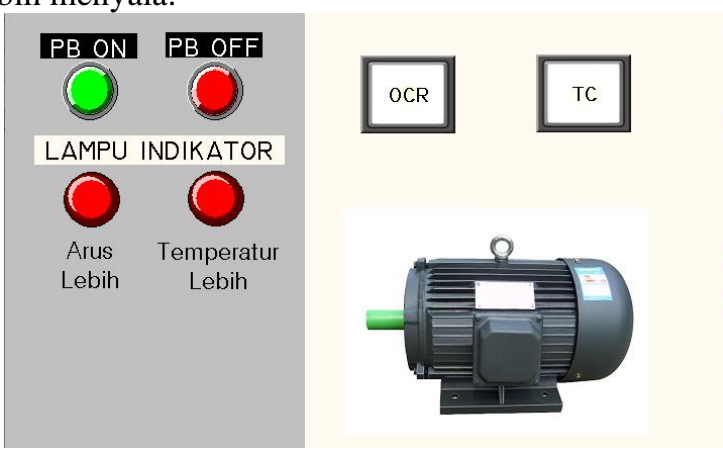

Gambar 18. Kondisi saat OCR dan TC aktif

Gambar 18. Menunjukkan kondisi motor ketika terjadi gangguan arus dan temperatur lebih yang ditandakan warna abu pada motor, juga OCR dan TC aktif lalu 
lampu indikator arus lebih dan temperatur lebih menyala.

\section{ANALISIS SIMULASI}

Berdasarkan simulasi yang telah dilakukan pada perangkat lunak CX-One, dalam ladder diagram yang dibuat menggunakan perangkat lunak CX-Programmer, garis berwarna hijau menunjukkan adanya aliran arus dan kontak yang berwarna hijau menandakan kontak dalam keadaan close atau aktif pada gambar 6 . Melihatkan ladder diagram dalam kondisi belum dijalankan, kemudian pada gambar 7. Melihatkan kondisi ladder diagram ketika PLC telah menyala, akan tetapi motor induksi belum dijalankan, untuk menjalankan motor induksi, kontak NO pada PB ON dihidupkan sehingga arus akan mengalir menuju motor seperti yang ditunjukkan pada gambar 8. Kemudian pada gambar 9. yang dimisalkan terjadi gangguan arus lebih yang melewati arus setting sebesar 3.421 A dengan mengaktifkan kontak NC OCR sehingga lampu indikator arus lebih menyala dan motor induksi akan mati. Begitu juga pada gambar 10. Yang dimisalkan terjadi gangguan temperatur lebih yang melebihi setting Temperature Controller yaitu sebesar $100^{\circ} \mathrm{C}$ kontak NC TC aktif lalu lampu indikator temperatur lebih menyala dan motor mati. Pada gambar 11. Terjadi gangguan arus dan temperatur lebih sehingga kontak OCR dan TC aktif dan motor mati. Kemudian pada gambar 12 . Menunjukkan keadaan lader diagram ketika kontak PB OFF NC dimatikan, arus yang mengalir menuju motor terhenti.

Dalam tampilan yang dibuat pada perangkat lunak CXDesigner terdapat dua buah push button yaitu PB On yang berwarna hijau dan PB Off yang berwarna merah, lalu terdapat dua buah lampu indikator yang berwarna merah padam saat kondisi off dan akan berwarna merah terang ketika menyala atau saat terjadi gangguan. Kemudian terdapat OCR dan TC yang digambarkan dengan kotak yang berwarna abu-abu ketika kondisi off dan akan berwarna putih saat kondisi on atau terjadi gangguan, dan terdapat motor yang berwarna abu saat kondisi off dan berwarna biru ketika kondisi menyala atau on.

\section{KESIMPULAN}

Berdasarkan pembahasan dari hasil simulasi sistem proteksi motor induksi tiga fasa dari arus dan temperatur lebih dengan mengaplikasikan PLC, maka dapat ditarik kesimpulan pemrograman PLC yang dilakukan pada perangkat lunak CX-Programmer dalam membuat Ladder Diagram sebagai sistem proteksi motor induksi tiga fasa telah dapat berjalan untuk mengamankan motor dari gangguan arus dan temperatur lebih, rancangan desain dari sistem proteksi motor induksi tiga fasa telah dibuat menggunakan perangkat lunak SketchUp dalam bentuk gambar tiga dimensi dan dibuat tampilan simulasi menggunakan perangkat lunak CXDesigner, penentuan setting OCR dan Temperature Controller ditentukan dari arus nominal dan kelas isolasi dari motor induksi tiga fasa tersebut. Didapatkan arus setting OCR sebesar 3.421 A dan Temperature Controller sebesar $100^{\circ} \mathrm{C}$.

\section{UCAPAN TERIMA KASIH}

Penulis mengucapkan terima kasih kepada Politeknik Negeri Bandung atas dukungan pendanaan Tugas Akhir melalui Skema Penelitian Peningkatan Kapasitas Laboratorium, sesuai nomor kontrak No.B/74.8/PL1.R7/PG.00.03/2021

\section{DAFTAR PUSTAKA}

[1] A. Wakhid, "Penerapan IoT Dalam Rancang Bangun Sistem Proteksi Motor Induksi Tiga Fasa Dari Gangguan Beban Lebih Berbasis Mikrokontroller," Skripsi. Pendidikan Teknik Elektro, Jurusan Teknik Elektro, Fakultas Teknik, Universitas Negeri Semarang. 2020.

[2] N.H. Ricardo, Junaidi dan H. Ayong, "Rancang Bangun Sistem Proteksi Motor Induksi Tiga Fasa Berbasis Mikrokontroler Atmega 16," Jurnal Mahasiswa Teknik Elektro Untan 1. 2017.

[3] I. Abdurahman, "Rancang Bangun Modul Praktikum Sistem Proteksi Motor Induksi Tiga Fasa Menggunakan Over Current Relay (OCR) SPAM 150c," Tugas Akhir, Program Studi D3 Teknik Listrik, Jurusan Teknik Elektro, Politeknik Negeri Bandung. 2020.

[4] Tasiam. "PROTEKSI SISTEM TENAGA LISTRIK" Yogyakarta : Tecnosain, 2017.

[5] Badan Standardisasi Nasional, "Persyaratan Umum Instalasi Listrik 2011 (PUIL 2011)," DirJen Ketenagalistrikan. 2011.

[6] NEMA Standard Publications, "Motors and Generators," National Electrical Manufactures Ascociation, Washington, No.MGI-1993, Part 21 PP. 9-10 and Part 30 PP. 1-2. 1993.

[7] I. Nyoman Bagia dan I. Made Parsa, "Motor-motor Listrik," Cetakan 1. Kupang : Cv. Rasi Terbit, 2018.

[8] Y. Indro Hatmojo, "Programmable Logic Control (PLC)," Jurusan Pendidikan Teknik Elektro, Fakultas Teknik, Universitas Negeri Yogyakarta. 2015.

[9] T. Timotius, "Pengggunaan Over Current Relay Dalam System Tenaga Listrik," Makalah, Prodi Pendidikan Teknik Elektro, Departemen Pendidikan Teknologi Dan Kejuruan,Universitas Nusa Cendana. 2016.

[10] D. Yeol Tadeus dan I. Setiono, "Deskripsi Teknis Pengendali Temperatur Industri Sebagai Bagian Dari Sistem Regulasi Temperatur," Jurnal GEMA TEKNOLOGI, Vol. 20, No. 1, 1-5. 2018.

[11] Musbikhin. (2013) : Pengantar CX Programmer (Seri Belajar PLC), https://www.musbikhin.com/pengantar-cxprogrammer-seri-belajar-plc/, Diakses pada 19 Mei 2021.

[12] 4winmobile. (2021) : SketchUp - Pengertian, Jenis, Fungsi, Kelebihan dan Kekurangannya, https://4winmobile.com/sketchup-pengertian-jenisfungsi-kelebihan-dan-kekurangannya/, Diakses pada 19 Mei 2021 